\title{
Tropical phytopathogens 2: Pseudocercospora fuligena
}

\author{
Phengsintham $P^{1,2,3}$, Chukeatirote $\mathrm{E}^{1,2}$,McKenzie EHC ${ }^{4}$, Hyde $\mathrm{KD}^{1,2}$ and Braun $\mathrm{U}^{5}$ \\ ${ }^{1}$ Institute of Excellence in Fungal Research, ${ }^{2}$ School of Science, Mae Fah Luang University, Chiang Rai 57100, \\ Thailand \\ ${ }^{3}$ Biology Department, Faculty of Sciences, National University of Laos, Laos \\ ${ }^{4}$ Landcare Research, Private Bag 92170, Auckland, New Zealand \\ ${ }^{5}$ Martin-Luther-Universität, Institut für Biologie, Bereich Geobotanik und Botanischer Garten, Herbarium, Neuwerk 21 \\ D-06099 Halle/S. Germany
}

Phengsintham P, Chukeatirote E, McKenzie EHC, Hyde KD, Braun U 2012 - Tropical phytopathogens 2: Pseudocercospora fuligena. Plant Pathology \& Quarantine 2(1), 57-62, doi $10.5943 / \mathrm{ppq} / 2 / 1 / 8$

Black leaf mold of tomato (Lycopersicon esculentum) is caused by Pseudocercospora fuligena, and the fungus and symptoms of the disease are illustrated and described. This cercosporoid disease causes leaf spots and spots on petioles, stems, and fruit peduncles (but not on the fruit itself). A detailed description of the lesion, morphological characters and partial sequence (273 bp) of the elongation factor 1-alpha (EF1a) gene of this species are provided.

Keywords - Anamorphic fungi - cercosporoid hyphomycetes - disease - morphology - tomato South East Asia.

\section{Article Information}

Received 4 May 2012

Accepted 7 May 2012

Published online 30 May 2012

*Corresponding author: Kevin D Hyde - kdhyde3@gmail.com

\section{Introduction}

Pseudocercospora fuligena (Rodan) Deighton causes black leaf mold of tomato (Lycopersicon esculentum Mill.) (HalfeldVieira1 et al. 2006). The disease has primarily been reported from Asia (Hartman et al. 1991, Jain 1955, Mohanty \& Mohanty 1955, Yamada 1951, Hsieh \& Goh 1990, Petcharat \& Kanjanamaneesathian 1989, Meeboon 2009). Major symptoms occur on the foliage but they may also occur on petioles, stems, and fruit peduncles (but not on the fruit itself) (AVRDC 2004). Hartman \& Wang (1992) studied black leaf mold development and its effect on tomato yield, and concluded that there was a significant negative correlation between the area under the disease progress curve and total yield, fruit number and weight per fruit (fruit number and weight was reduced to $20 \%$ and $7 \%$, respectively, as compared to the control).
As part of a programme to study cercosporoid fungi in Thailand and Laos, we commonly identified this species. In this paper we describe its role as an important tropical plant pathogen, with illustrations and description, and notes on host symptoms.

\section{Host}

Tomato (Lycopersicon esculentum $\equiv$ Solanum lycopersicum) belongs to family Solanaceae. Plants typically grow to 1-3 metres in height but due to a weak stem, plants often sprawl over the ground or over other plants. Originating in South America, the tomato has spread around the world following the Spanish colonization of the Americas, and its many varieties are now widely grown, often in greenhouses in cooler climates (Wikipedia 2012). 




Fig. 1 - Leaf spots caused by Pseudocercospora fuligena.

The tomato fruit is consumed in diverse ways, including raw, as an ingredient in many dishes and sauces, and in drinks. The fruit is rich in lycopene, which may have beneficial health effects. Tomatoes and tomato sauces and puree are said to help lower urinary tract symptoms (BPH) and may have anti-cancer properties (Polivkova et al. 2010).

Gleason \& Edmunds (2006) studied tomato diseases and disorders, and concluded that various fungal taxa [Alternaria solani, Cladosporium fulvum (now Passalora fulva), Colletotrichum coccodes, Fusarium oxysporum f. sp. lycopersici, Phytophthora infestans, Septoria lycopersici], bacteria (Pseudomonas syringae pv. tomato, Xanthomonas campestris pv. vesicatoria) and viruses were the major biotic diseases.

There is limited information about black leaf mold (Pseudocercospora fuligena) and its causal agent. The disease was first described in the Philippines in 1938 and the pathogen described as Cercospora fuligena (Hartman \& Wang 1992). Deighton (1976) transferred the fungus to the genus Pseudocercospora.

\section{Symptoms}

Symptoms appear as foliar spots, 2-8 $\mathrm{mm}$ diam., yellow on upper surface, and brown to dark brown on the lower surface; brown to dark brown in the centre, and with yellowish to yellowish brown margin (Fig. 1).

\section{Taxonomy}

\section{Pseudocercospora fuligena (Roldan)}

Deighton, Mycol. Pap. 140: 144 (1976).

Figs 2, 3.

$$
\equiv \text { Cercospora fuligena Roldan, Philipp. }
$$

J. Sci. 66: 8 (1938).

Description - Caespituli/Colonies amphigenous, but chiefly hypophyllous. Mycelium internal; hyphae branched, 1-4 $\mu \mathrm{m}$ wide $(\bar{x}=2.86 \mu \mathrm{m}, \mathrm{n}=21)$, septate, constricted at the septa, distance between septa 4-15 $\mu \mathrm{m}(\bar{x}=9.14 \mu \mathrm{m}, \mathrm{n}=21)$, subhyaline or hyaline, wall $0.3-0.5 \mu \mathrm{m}$ wide $(\bar{x}=0.38 \mu \mathrm{m}, \mathrm{n}$ $=21)$, smooth. Stromata well developed, substomatal, subglobular, $15-25 \mu \mathrm{m}$ diam. $(\bar{x}$ $=0.38 \mu \mathrm{m}, \mathrm{n}=10$ ), brown to dark brown, stromatal cells oval, ellipsoidal to angular in outline, $3-6 \mu \mathrm{m}$ wide $(\bar{x}=4.43 \mu \mathrm{m}, \mathrm{n}=30)$, 


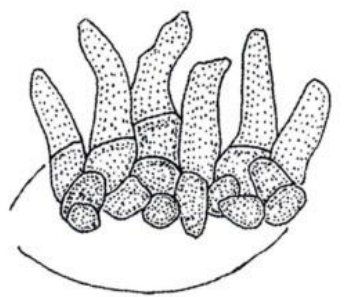

1

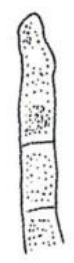

2

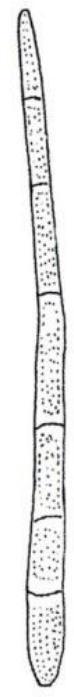

3

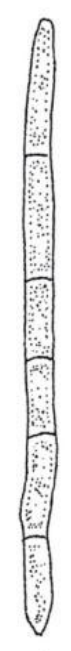

4

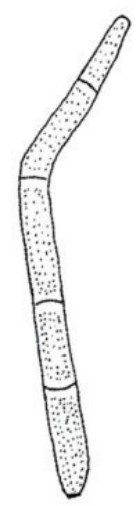

5



6
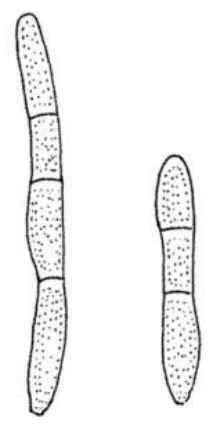

$7 \quad 8$

Fig. 2 - Pseudocercospora fuligena. 1 Stroma and conidiophores. 2 Conidiophore. 3-8 Conidia. Bar $=10 \mu \mathrm{m}$.

brown, wall $0.5-1 \mu \mathrm{m}$ wide $(\bar{x}=0.68 \mu \mathrm{m}, \mathrm{n}=$ 30), smooth. Conidiophores fasciculate, arising from stromata (4-18 per fascicle), erect, straight or curved, not branched, 8-31 $\times 4-5$ $\mu \mathrm{m}(\bar{x}=16.1 \times 4.32 \mu \mathrm{m}, \mathrm{n}=30), 0-2$-septate, distance between septa $4-23 \mu \mathrm{m}(\bar{x}=9.43 \mu \mathrm{m}$, $\mathrm{n}=30$ ), pale to moderately olivaceous-brown, paler and narrower towards the apex, wall $0.5-$ $0.8 \mu \mathrm{m}$ wide $(\bar{x}=0.67 \mu \mathrm{m}, \mathrm{n}=30)$, smooth. Conidiogenous cells integrated, terminal or conidiophores reduced to conidiogenous cells, straight, cylindrical to conical or somewhat geniculate-sinuous, $8-19 \times 3-5 \mu \mathrm{m}(\bar{x}=12.9$ $\times 4.12 \mu \mathrm{m}, \mathrm{n}=30$ ), pale olivaceous or brown; conidiogenous loci inconspicuous or subdenticulate, but wall always unthickened and not darkened. Conidia solitary, cylindrical to cylindrical-obclavate, straight to moderately curved, $21-76 \times 2.5-4 \mu \mathrm{m}(\bar{x}=49.67 \times 3.12$ $\mu \mathrm{m}, \mathrm{n}=30), 1-6$-septate, slightly constricted at the septa, pale olivaceous, wall $0.3-0.5 \mu \mathrm{m}$ wide $(\bar{x}=0.4 \mu \mathrm{m}, \mathrm{n}=30)$, smooth, rounded at the apex, base obconically truncate, hilum neither thickened nor darkened.

Known hosts - Solanaceae) Capsicum annuum L., C. baccatum L., C. chinense Jacq., C. frutescens L., Lycopersicon chilense Dunal, L. chmielewskii C.M. Rick, Kesicki, Fobes \& M. Holle, L. esculentum Mill., L. glandulosum C.H. Mull., L. parviflorum C.M. Rick, Kesicki, Fobes \& M. Holle, L. pennellii (Correll) D'Arcy, L. peruvianum Mill., L. pimpinellifolium L., Solanum indicum L., S. melongena L. and S. nigrum L. (Crous \& Braun 2003).

Known distribution - Africa: Gabon, Gambia, Ivory Coast, Nigeria, Senegal, Somalia, Tanzania, Togo, Uganda; Asia: Bangladesh, Brunei, Cambodia, China, Hong Kong, India, Japan, Laos, Malaysia, Philippines, Taiwan, Thailand, Vietnam; Europe: Belarus; North America: Mexico, USA (FL); Caribbean: Cuba, Netherlands Antilles; Oceania: Australia, Cook Islands, New Caledonia, New Zealand, Palau, Papua New Guinea, Solomon Islands, Vanuatu; South America: Brazil, Chile. 


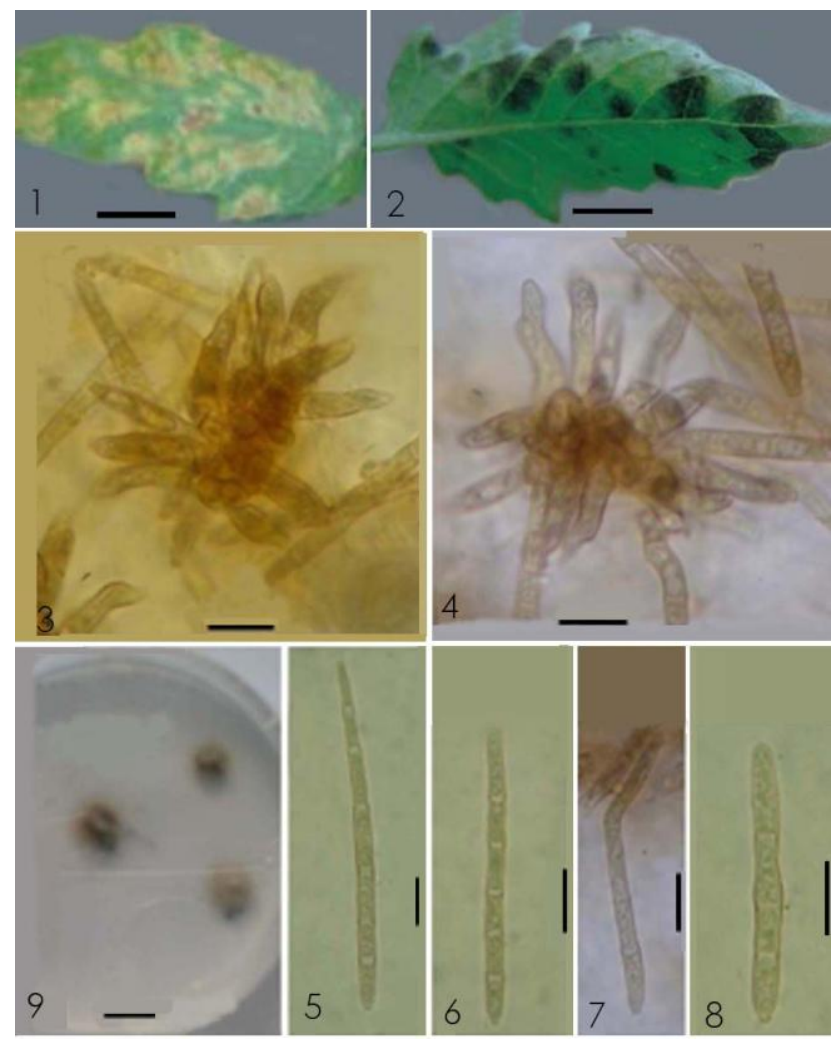

Fig. 3 - Pseudocercospora fuligena from leaf spots on Lycopersicon esculentum. 1-2 Lesions on host leaves (1. upper surface, 2. lower surface). 3-4 Stromata and conidiophores. 5-8 Conidia. 9 Culture. Bars 1, 2=10 mm, 3-8 = $10 \mu \mathrm{m}, 9=10 \mathrm{~mm}$.

Material examined - Thailand, Chiang Rai Province, Tasud Meuang District, Sri Pangsang Village, on leaf of Lycopersicon esculentum, 3 June 2010, P. Phengsintham, MFLU 12-0001. Culture = MFLUCC 12-0001, GenBank accession no JQ837455; Laos, Vientiane Capital, Xaythany District, Xay Village, on leaf of Lycopersicon esculentum, 14 May 2006, P. Phengsintham, NUOL P49.

Cultural characteristics - Mycelial colonies on PDA after 3 weeks at $25^{\circ} \mathrm{C} 10-13$ $\mathrm{mm}$ diam., grey-brown, surface ridged and smooth, hyphae $2-11 \mu \mathrm{m}$ wide $(\bar{x}=4.77 \mu \mathrm{m}$, $\mathrm{n}=30)$, septate, constricted at the septa, distance between septa 5-16 $\mu \mathrm{m}(\bar{x}=10.97$ $\mu \mathrm{m}, \mathrm{n}=30)$, brown, wall $0.3-1 \mu \mathrm{m}$ wide $(\bar{x}=$ $0.54 \mu \mathrm{m}, \mathrm{n}=30$ ), smooth. Conidiophores and conidia not formed in culture.

Remarks - Chupp (1954) mentioned that Cercospora canescens, C. physalidis and $C$. diffusa have been reported on tomato, but it is probable that there was a mistake in species identify. The conidial septation and size of Pseudocercospora fuligena as reported by various authors are shown in Table 1.

Tomato leaf mould caused by Passalora fulva (syn. Cladosporium fulvum,
Fulvia fulva), causes similar symptoms to that caused by Pseudocercospora fuligena. The two diseases can be distinguished with certainty only by a microscopic examination of the sporulating mould growth (McKenzie 1983).

The partial sequences of the internal transcribed spacer $1,5.8 \mathrm{~S}$ ribosomal RNA gene, internal transcribed spacer 2 , and $28 \mathrm{~S}$ ribosomal RNA gene, complete sequence of $P$. fuligena was $5531 \mathrm{bp}$, GenBank number (GU 214675) (http://www.ncbi.nlm.nih.gov/nuccore/?term=Pseudocercospora\%20fuligena).

We also describe here a partial sequence of the elongation factor 1-alpha (EF1a) gene (EF728f and EF986R) of the elongation factor 1-alpha (EF1a) gene of $P$. fuligena. For this, the genomic DNA from fungal mycelium was extracted from mycelia following the protocols as outlined by Cai et al. (2006). The incomplete sequence of the EF1a gene was then amplified using the primers EF728f and EF986R and sequenced using the same primers by SinoGenoMax Company limited, China. The sequence obtained was 273 bp and is deposited in GenBank (JQ837455). This sequence information may be useful for phylogenetic study in future work. 
Table 1 Reported conidial size and septation of Pseudocercospora fuligena.

\begin{tabular}{lll}
\hline Septa & Conidia Size $(\boldsymbol{\mu m})$ & References \\
\hline Multiseptate & $15-120 \times 3-5.5$ & Chupp $(1954)$ \\
$3-9$-septate & $20-120 \times 4-5$ & Ellis $(1976)$ \\
2-9-septate & $20-90 \times 2.5-4$ & Hsieh \& Goh $(1990)$ \\
$3-10$-septate & $20-100 \times 3-6$ & Guo \& Hsieh $(1995)$ \\
$1-6$-septate & $21-76 \times 2.5-4$ & Present study \\
\hline
\end{tabular}

\section{Management of the Disease}

Management of tomato diseases requires multiple tactics:

- select best possible site,

- improve soil quality,

- practice appropriate rotations,

- manage water properly,

- choose varieties with best resistance available.

\section{Acknowledgements}

The authors would like to thank the Mushroom Research Foundation (MRF) for financial support. Special thanks also go to the MRF organizers and members of Prof. K.D. Hyde's laboratory, Mae Fah Luang University (MFU) for their assistance.

\section{References}

AVRDC. 2004 - Black leaf mold. The World Vegetable Center Publication, 4, 606.

Cai L, Jeewon R, Hyde KD. 2006 Phylogenetic investigations of Sordariaceae based on multiple gene sequences and morphology. Mycological Research 110: 137-150.

Chupp C. 1954 - A Monograph of the Fungus Genus Cercospora. Ithaca, New York.

Crous PW, Braun U. 2003 - Mycosphaerella and its anamorphs: 1. Names published in Cercospora and Passalora. CBS Biodiversity Series 1, 1-569.

Deighton FC. 1976 - Studies on Cercospora and allied genera. VI. Pseudocercospora Speg., Pantospora Cif. and Cercoseptoria Petr. Mycological Papers 140, 1-168.

Ellis MB. 1976 - More Dematiaceous Hyphomycetes. Commonwealth Mycological Institute, Kew, Surrey, England. p. 507.

Gleason ML, Edmunds BA. 2006 - Tomato diseases and disorders. Department of Plant Pathology, Instructional Technology Center, Iowa State University.

Guo YI, Hsieh WH. 1995 - The genus Pseudocercospora in China. International Academic Publisher.

Halfeld-Vieira1 BA, Nechetl KL, Barbosall RNT. 2006 - Pseudocercospora fuligena causing leaf mold of tomato in Roraima, Brazil. Fitopatologia Brasileira 31, 320.

Jain AC. 1955 - Cercospora leaf spots of tomato. Science and Culture 21, 42-43.

Hartman GL, Wang TC. 1992 - Black leaf mold development and its effect on tomato yield. Plant Disease 76, 462465.

Hartman GL, Chen SC, Wang TC. 1991 Cultural studies and pathogenicity of Pseudocercospora fuligena, the causal agent of black leaf mold of tomato. Pant diseases 75: 1060-1065.

Hsieh WH, Goh TK. 1990 - Cercospora and Similar Fungi from Taiwan. Maw Chang Book Company, Taipei, Taiwan.

McKenzie EHC. 1983 - Tomato leaf mould. South Pacific Commission Advisory Leaflet 15.

Meeboon J. 2009 - Diversity and phylogeny of true cercosporoid fungi from northern Thailand. Ph.D. Thesis, Chiang Mai University, Thailand (unpublished).

Mohanty UN, Mohanty NN. 1955 Cercospora leaf mold of tomato. Science and Culture 21, 269-270.

Petcharat V, Kajanamaneesathian M. 1989 Species of plant pathogenic Cercospora in southern Thailand. Thai Journal of Phytopathology 9, 23-27.

Polívková Z, Šmerák P, Demová H, Houška M. 
Plant Pathology \& Quarantine Doi 10.5943/ppq/2/1/8

2010 - Antimutagenic effects of lycopene and tomato purée. Journal of Medicinal Food 13, 1443-1450.

Wikipedia 2012 - http://en.wikipedia.org/wiki/Tomato
Yamada S. 1951 - New disease of tomato (Lycopersicon esculentum Mill.) caused by Cercospora sp. Annals of the Phytopathological Society of Japan 15, 13-18. 